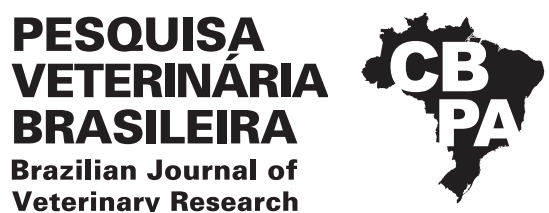

\title{
Uncommon anatomical sites and anatomopathological presentations of lymphoma in $\operatorname{dog} \mathbf{s}^{1}$
}

\author{
Renata D. Mazaro², Flávia S. Luz², Alana P. Herbichi ${ }^{3}$, Douglas M. Lorenzetti ${ }^{3}$, \\ Bruno Cogliati ${ }^{4}$ (D) and Rafael A. Fighera ${ }^{5 *}$ (D)
}

\begin{abstract}
Mazaro R.D., Luz F.S., Herbichi A., Lorenzetti D.M., Cogliati B. \& Fighera R.A. 2020. Uncommon anatomical sites and anatomopathological presentations of lymphoma in dogs. Pesquisa Veterinária Brasileira 40(4):271-283. Departamento de Patologia, Universidade Federal de Santa Maria, Av. Roraima 1000, Santa Maria, RS 97105-900, Brazil. E-mail: anemiaveterinaria@yahoo.com.br

Lymphomas are the tumors most frequently associated with the death or euthanasia of dogs in most parts of the world. In dogs, they almost always occur as disseminated (multicentric lymphoma), gastrointestinal (alimentary lymphoma), or nodal mediastinal (mediastinal lymphoma) diseases. However, other uncommon presentations can occasionally occur. This study aimed to establish the prevalence of these unusual types of lymphoma and demonstrate to veterinary pathologists how they present pathologically. From a total of 100 cases of lymphoma in dogs diagnosed between 1965 and 2017, 16 cases (16/100) were considered by us as non-traditional presentations of the disease: follicular lymphoma, (5/100), peripheral T-cell lymphoma, NOS (2/100), angiocentric lymphoma $(2 / 100)$, intravascular large T-cell lymphoma (2/100), lymphomatoid granulomatosis $(1 / 100)$, anaplastic largecell lymphoma (1/100), hepatosplenic T-cell lymphoma (1/100), and chronic small B-cell lymphocytic lymphoma, intermediate type $(1 / 100)$. We hope that the results presented here can help veterinary pathologists to recognize such cases of "atypical lymphoma" in their diagnostic routines.
\end{abstract}

INDEX TERMS: Anatomical sites, anatomopathological, lymphoma, dogs, non-traditional lymphomas, atypical lymphomas.

\begin{abstract}
RESUMO.-[Sítios anatômicos e apresentações anatomopatológicas incomuns do linfoma em cães.] Linfomas são os tumores mais associados a morte ou eutanásia de cães na maior parte do mundo. Nessa espécie animal ocorrem quase sempre como uma doença disseminada (linfoma multicêntrico), gastrintestinal (linfoma alimentar) ou nodal mediastinal (linfoma mediastínico), entretanto, ocasionalmente, outras apresentações bem menos comuns podem ser encontradas. 0 objetivo deste artigo é estabelecer a prevalência desses pouco usuais tipos de linfoma e demonstrar aos patologistas veterinários como eles se apresentam
\end{abstract}

\footnotetext{
${ }^{1}$ Received on September 2, 2019.

Accepted for publication on September 9, 2019.

${ }^{2}$ Graduate Studies Program in Veterinary Medicine, concentration in Pathology and Veterinary Clinical Pathology, Patologia e Patologia Clínica Veterinária, Centro de Ciências Rurais (CCR), Universidade Federal de Santa Maria (UFSM), Av. Roraima 1000, Camobi, Santa Maria, RS 97105-900, Brazil.

${ }^{3}$ Curso de Medicina Veterinária, Centro de Ciências Rurais (CCR), Universidade Federal de Santa Maria (UFSM), Av. Roraima 1000, Camobi, Santa Maria, RS 97105-900.
}

anatomopatologicamente. De um total de 100 casos de linfoma em cães diagnosticados entre os anos de 1965 e 2017, 16 casos (16/100) foram considerados como apresentações não tradicionais da doença: linfoma folicular (5/100), linfoma de células T periférico inespecífico $(2 / 100)$, linfoma angiocêntrico $(2 / 100)$, linfoma intravascular de grandes células T (2/100), granulomatose linfomatoide $(2 / 100)$, linfoma de grandes células anaplásicas $(1 / 100)$, linfoma hepatoesplênico de células T $(1 / 100)$ e linfoma linfocítico crônico de pequenas células B - tipo intermediário (1/100). Esperamos que os resultados aqui demonstrados auxiliem patologistas

\footnotetext{
${ }^{4}$ Laboratório de Patologia Morfológica e Molecular (LAPMOL), Faculdade de Medicina Veterinária e Zootecnia (FMVZ), Universidade de São Paulo (USP), Avenida Prof. Dr. Orlando Marques de Paiva 87, Cidade Universitária, Butantã, São Paulo, SP 05508-270, Brazil.

${ }^{5}$ Departamento de Patologia, Centro de Ciências da Saúde (CCS), Universidade Federal de Santa Maria (UFSM), Av. Roraima 1000,Camobi, Santa Maria, RS 97105-900. *Corresponding author: anemiaveterinaria@yahoo.com.br
} 
veterinários a reconhecerem tais casos de "linfomas atípicos" em suas rotinas diagnósticas.

TERMOS DE INDEXAÇÃO: Sítios anatômicos, anatomopatológicas, linfoma, cães, linfomas raros, linfomas não tradicionais, linfomas atípicos.

\section{INTRODUCTION}

Lymphoma, also known as lymphosarcoma, is a malignant neoplasm originating from $B$ lymphocytes, $T$ lymphocytes, or null cells (non-B and non-T, natural killer cells - NK) that, except for the bone marrow, most commonly arise from organs/hematopoietic tissues, including lymph nodes or spleen, and mucosa-associated lymphoid tissue (MALT) (Valli 2007, Vezzali et al. 2009, Ponce et al. 2010, Swerdlow et al. 2017). In dogs, the annual prevalence of lymphoma in the United States is 13 to 24 cases per 100,000 animals (Dorn et al. 1987). In Europe, lymphoma accounts for $20.1 \%$ and $8.4 \%$ of cancers in males and females, respectively (Merlo et al. 2008). In Brazil, lymphoma represents $8.8 \%$ of all cancers affecting dogs, observed at necropsy, and accounts for $1 \%$ of the causes of death or reasons for euthanasia in this animal species (Fighera 2008), being more critical in males $(13 \%$ of tumors responsible for spontaneous death or euthanasia) than in females ( $6 \%$ of tumors responsible for spontaneous death or euthanasia) (Flores 2016).

The most common presentation of lymphoma in dogs is characterized by widespread involvement of superficial and/or deep lymph nodes (generalized lymphadenopathy), concomitant or not with involvement of the spleen, liver and, less frequently, tonsils and bone marrow (multicentric lymphoma (Vail 2004, Couto 2010, Helfand \& Kisseberth 2010, Fry \& McGavin 2012, Vail et al. 2013, Fighera \& Graça 2016). Macroscopically, in this form of presentation, lymph nodes are diffusely enlarged (lymphadenomegaly), whitish or variably reddish, soft and succulent, not allowing corticomedullary delimitation to the cut surface (diffuse pattern) (Vail 2004, Couto 2010, Helfand \& Kisseberth 2010, Fry \& McGavin 2012, Vail et al. 2013, Fighera \& Graça 2016). The spleen and liver show diffuse swelling (diffuse hepatosplenomegaly) (Helfand \& Kisseberth 2010, Fry \& McGavin 2012, Fighera \& Graça 2016). When the tonsils are affected, they lose their pleated conformation and stand out as bilaterally symmetrical, non-ulcerated masses (diffuse tonsilomegaly) (Fighera \& Graça 2016). By highlighting the final stage of lymphoma, neoplastic lymphocytes released from the affected organs can colonize the bone marrow, leading to medullary involvement (Fighera et al. 2002).

The second most common presentation of lymphoma in dogs occurs when there is diffuse enlargement of the mesenteric lymph nodes (localized lymphadenomegaly), with a gross lesion pattern similar to the one previously described, and/or when segments of the gastrointestinal tract (GIT) present nodules of transmural, mucosal to serous infiltration, or diffuse segmental thickening of the mucosa or submucosa (alimentary lymphoma) (Vail 2004, Couto 2010, Helfand \& Kisseberth 2010, Fry \& McGavin 2012, Vail et al. 2013, Fighera \& Graça 2016). Secondarily, due to neoplasm progression, the liver and regional lymph nodes may be affected (Fry \& McGavin 2012).

The third but less commonly observed presentation of lymphoma in dogs involves the mediastinal lymph nodes and/ or the thymus (Vail 2004, Couto 2010, Helfand \& Kisseberth 2010, Fry \& McGavin 2012, Vail et al. 2013, Fighera \& Graça 2016). The lymph nodes appear diffusely enlarged with a gross pattern similar to that previously described, or as only a large homogeneously yellowish white, soft tumor mass occupying the mediastinum and, sometimes, a large part of the thoracic cavity (mediastinal lymphoma) (Helfand \& Kisseberth 2010, Fry \& McGavin 2012, Vail et al. 2013, Fighera \& Graça 2016).

Regarding the histopathology of canine lymphoma, the diffuse architectural pattern is predominant over the nodular pattern, representing 87.7 to $98.8 \%$ of the diagnoses in the literature, indicating that follicular lymphoma, which so common in humans, is rare in dogs (Sueiro et al. 2004, Arespacochaga et al. 2007, Vezzali et al. 2009, Ponce et al. 2010). Based on the different lymphoma classification systems, a large microscopic variety of types and subtypes has been described (Valli et al. 2017). However, most lymphomas already diagnosed in dogs are represented by five recognized types and/or subtypes according to the histological criteria established by the World Health Organization (WHO) for the classification of hematopoietic tumors in animals (Valli 2002) as: 1) diffuse large B-cell lymphomas (47 [Ponce et al. 2010] to $54.4 \%$ [Vezzali et al. 2009]), which include centroblastic, immunoblastic, and B-cell rich T-cell histiocyte lymphomas; 2) lymphoblastic lymphomas (2.8 [Ponce et al. 2010] to $10.7 \%$ [Vezzali et al. 2009]), which may arise from B or T cells; 3 ) small B-cell lymphocytic lymphomas (1..8 [Ponce et al. 2010] to 7.8\% [Vezzali et al. 2009]), which include chronic lymphocytic lymphoma and lymphoplasmocytic lymphoma ("immunocytoma"); 4) marginal zone lymphomas (10.8\% [Ponce et al. 2010]); 5) peripheral T-cell lymphomas, not otherwise specified (NOS) (6.8 [Vezzali et al. 2009] to 13.6\% [Ponce et al. 2010]).

Based on the information previously described, veterinary pathologists working in the field of dog disease diagnosis will often encounter mainly cases of multicentric lymphoma and, occasionally, cases of alimentary and mediastinal lymphoma. More rarely, however, these same pathologists may encounter unusual cases of lymphoma in their routines, in which: 1 ) only a single lymphoid organ other than the lymph node is affected (solitary lymphoma), 2) one or more non-lymphoid organs are affected (extranodal lymphoma), 3) an uncommon combination of lymphoid and non-lymphoid organs (mixed lymphoma), or 4) a gross presentation of lymphoma different from that traditionally described in the literature, i.e., lymphomas that do not occur as "diffuse organomegaly". Generally, these cases reflect distinct microscopy, which bears no resemblance to the traditional histopathological patterns previously considered common to the species (diffuse large B-cell lymphomas, lymphoblastic lymphomas, small B-cell lymphomas, marginal zone lymphomas, and peripheral T-cell lymphomas, NOS). Thus, lymphomas that occur in unusual anatomical sites and/or present anatomopathologically (macroscopically and/or at histopathology) are infrequently described in the medical and veterinary literature, according to each author, by the adjectives "unusual" or "rare". Therefore, this study aims to demonstrate to veterinary pathologists interested in canine oncopathology that, although such lymphomas are not very prevalent, they do occur, and their recognition is fundamental for excellent diagnostics in their necropsy or surgical pathology routines. 


\section{MATERIALS AND METHODS}

Reports of the dog necropsies performed at the "Laboratório de Patologia Veterinária" of the "Universidade Federal de Santa Maria" (LPV-UFSM) between 1965 and 2017 were used to collect data on cases of lymphoma. For this study, we considered only cases in which the presentation of lymphoma was not classically observed i.e., 1) unusually affecting anatomical sites; 2) gross patterns little or not described in the literature, and 3) histological types or subtypes reported only occasionally in dogs. From the necropsy reports selected for the study, we collected macroscopic and histopathological information about each case. When possible, the cases were reassessed macroscopically using images from the LPV-UFSM. Subsequently, all cases were histologically reevaluated by making slides from the cut-out hematoxylin-eosin (HE)-stained, paraffin-embedded tissues. The definitive diagnosis of the tumor was based on the World Health Organization (WHO) histological criteria for the classification of hematopoietic tumors in humans (Swerdlow et al. 2017) and for the classification of hematopoietic tumors in domestic animals published by Armed Forces Institute of Pathology (AFIP) (Valli 2002), including its most recent update (Valli et al. 2017).

In order to determine the origin of the neoplastic lymphocytes and for classification purposes, at least one affected tissue from each of these cases was selected and analyzed by immunohistochemistry (IHC). The technique employed was B-lymphocyte immunostaining using CD79 (Clone JCB117, Dako Cytomatic, mouse-produced) or CD20 (RB9013-P, ThermoScientific, rabbit-produced) antibodies and T-lymphocyte immunostaining CD3 (Clone F7.2.38, Dako Cytomatic, mouse-produced) antibody. IHC was performed according to the following protocol: After tissue deparaffinization and rehydration, antigen recovery using Tris-EDTA solution ( $\mathrm{pH}$ 9.0) was performed in microwave oven at high power for $10 \mathrm{~min}$. Endogenous peroxidase blockade was performed using 3\% hydrogen peroxide for 20 min. Nonspecific reactions were blocked using Protein Block at room temperature for $10 \mathrm{~min}$. The primary antibody was antiCD79 monoclonal (prediluted) or anti-CD20 polyclonal (1:800 dilution) (ScyTek - ATG 125), and anti-CD3 monoclonal antibody (prediluted). Both antibodies were incubated in oven at $37{ }^{\circ} \mathrm{C}$ for $60 \mathrm{~min}$ or in refrigerator at $7{ }^{\circ} \mathrm{C}$ for $16 \mathrm{~h}$ (overnight). Secondary antibodies and Horseradish peroxidase (HRP) polymer were used consecutively incubated at $25{ }^{\circ} \mathrm{C}$ for $30 \mathrm{~min}$ and developed by adding 3-3'diaminobenzidine (DAB) tetrachloride chromogen for 5 min. Counterstaining was performed using Harris Hematoxylin. Dog lymph nodes and tonsils were used as positive and negative controls, respectively. Negative control was obtained by omitting the primary antibody using only the antibody diluent.

\section{RESULTS}

All cases included in this study occurred in the municipality of Santa Maria, located in the midwestern mesoregion of the state of Rio Grande do Sul (29 $32^{\prime} 52^{\prime \prime}$; 5342'10'), popularly known as central region. From 1965 to 2017, 9020 dogs were necropsied at the VPL-UFSM. Of these, 100 died or were euthanized, and lymphoma was diagnosed in approximately $1 \%$ at necropsy. Of the 100 necropsied dogs, 16 cases (16/100) were considered by us as "nontraditional" lymphoma presentations, featuring eight lymphoma types and/or histological subtypes, namely, follicular lymphoma (5/100), peripheral T-cell lymphoma, NOS (2/100), angiocentric lymphoma (2/100), intravascular large T-cell lymphoma (2/100), lymphomatoid granulomatosis (2/100), anaplastic large-cell lymphoma (1/100), hepatosplenic T-cell lymphoma (1/100), and B-cell chronic small lymphocytic lymphoma, intermediate type (1/100). The anatomopathological findings of each case will be described below.

\section{Follicular lymphoma}

Of all dogs diagnosed with lymphoma $(n=100)$, five $(5 / 100)$ corresponded to follicular lymphoma. All necropsied dogs presented diffuse and markedly enlarged superficial and deep lymph nodes (generalized lymphadenomegaly), whitish to slightly reddish, and soft to the touch. When cut, they were equally soft and allowed a minimal amount of translucent liquid to flow. The cut surface was damp, shiny, white or mottled white and red, but characteristically dotted with tens to hundreds of white nodules of varying size, multifocal or coalescing (nodular pattern) that did not allow corticomedullar delimitation (Fig.1). In all cases, the spleen was diffuse and markedly enlarged (diffuse splenomegaly), which was evidenced by the rounding of its edges and displacement of its anatomical position in the abdominal cavity. Three gross patterns were identified on the natural surface. In one of them, observed in three of the five cases, the surface was red, smooth, and filled with myriads of multifocal or coalescing white dots of varying sizes (nodular pattern). In another pattern, observed in one of the five cases, the surface was homogeneously red and smooth, but without the white dots described in the previous three cases. In the last pattern, also observed in one of the five cases, the surface was markedly irregular, dotted with hemispherically elevated white dots. Despite these three distinct patterns, at the cutting surface, the spleen was always characterized by a white or pinkish, bright or glassy, random, multifocal, or coalescing dotted line, macroscopically similar to that described for diffuse white pulp hyperplasia (Fig.1).

At histopathology, all cases presented, both in the lymph nodes and the spleen, a dense cell population, with an organization pattern characterized by nodules of variable dimensions, moderately or markedly defined, not encapsulated, absence of mantle zone, and without noticeable stroma (Fig.2). In the lymph nodes, these nodules invaded the capsule and obliterated the subcapsular and peritrabecular sinuses. Carefully arranged neoplastic nodules, divided or not by delicate connective tissue trabeculae, extended from the cortical to the medullary region, almost entirely replacing the parenchyma and the lymphoid follicles, including their polarization, and the hematopoietic components of the cord could not be visualized. In the spleen, the parenchyma was similarly replaced by closely related and identical nodules. These nodules were composed of neoplastic lymphocytes distributed in the form of a mantle and separated by splenic structures, sometimes by discrete remaining segments of the red pulp. Predominantly, neoplastic lymphocytes had a moderate amount of homogeneous and eosinophilic cytoplasm. Rounded oval nuclei consisting of loose or vesicular chromatin, including one to four prominent, mainly peripheral, large eosinophilic nuclei, often in contact with a nuclear membrane, were observed. At IHC, neoplastic cells were immunostained for B lymphocytes (anti-CD20), and small groups of normal lymphocytes distributed randomly throughout the remaining tissue showed positivity for the $\mathrm{T}$ lymphocyte marker (anti-CD3). 


\section{Peripheral T-cell lymphoma, NOS}

Two cases of peripheral T-cell lymphoma were found in this study (2/100). In one case (1/100), there was concomitant involvement of the lungs, stomach, liver, and lymph nodes (hepatic, gastric, and pancreatic). At necropsy, pulmonary involvement stood out compared with those of the other affected organs. Neither lung collapsed upon opening of the thoracic cavity. They were heavy, moist, shiny, reddish, and soft. The middle lobe of the right lung was homogeneously reddish, opaque, and firm to the touch (pulmonary hepatization). Additionally, there were multifocal nodules distributed throughout the natural surface of the pulmonary lobes, except for the consolidated lobe, as well as several non-elevated and few elevated white, soft umbilicated annular parenchyma areas ranging from 0.1 to $1.5 \mathrm{~cm}$ in diameter (Fig.3). At cut, the lungs were soft with homogeneously red surface close or not to multifocal or coalescing whitish hemispheric nodules. The consolidated lobe (middle lobe) was firm at cut, with consistency similar to flesh ("pulmonary carnification").

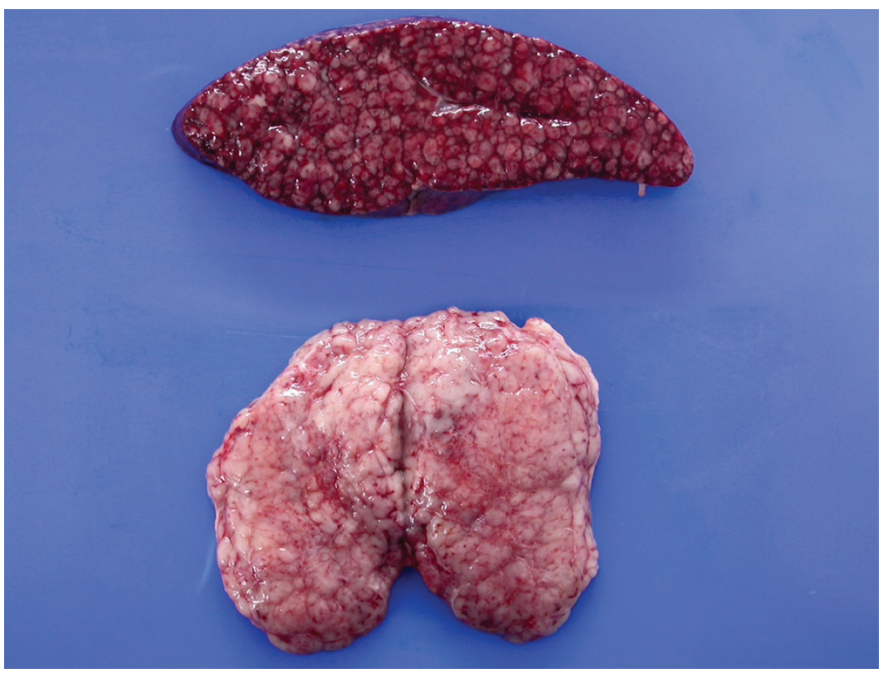

Fig.1. Follicular lymphoma, spleen and lymph node (cut surface), dog. Presence of a multifocal and coalescing white and bright dotted.

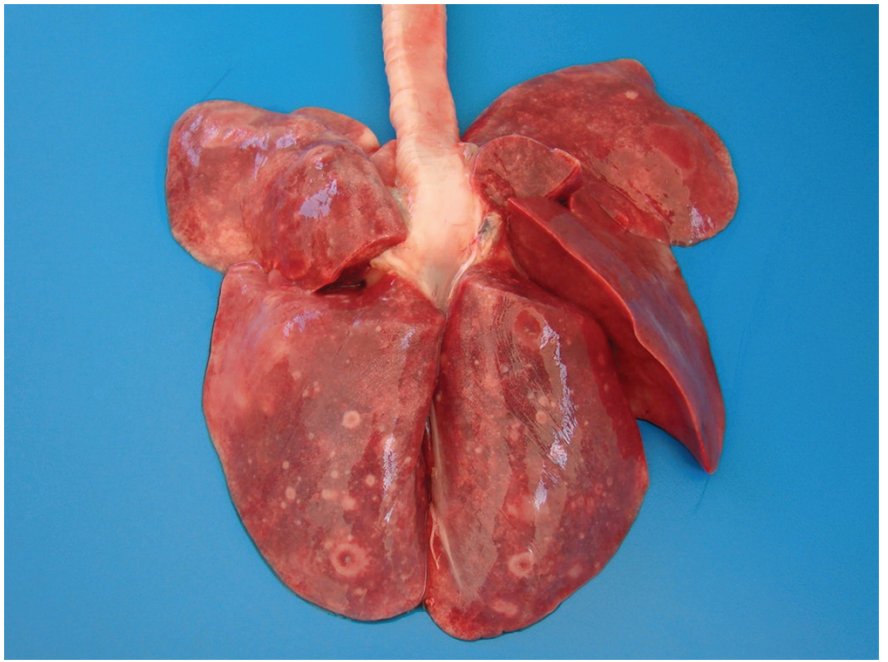

Fig.3. Peripheral T-cell lymphoma, NOS, lung, dog. Absence of collapse ("armed lungs") and intense reddening give the organ a hepatized appearance. Note the various white, non-elevated annular parenchyma areas, some similar to a target.
In the other case (1/100), the heart was the only organ affected. Macroscopically, there were non-elevated yellowish white areas with multifocal distribution or coalescing in the epicardium, both on the left (atrial) and right (atrial) chambers, but sparing the vessels. Transverse sectioning at the ventricle level showed that the externally observed areas presented an equally yellowish white cut surface and extended through the myocardium, including the papillary muscle of both ventricles and, in some places, reached the endocardium (transmural involvement) of right atrium and ventricle (Fig.4). The proliferated tissue caused moderate diffuse thickening of the left atrium.

Histologically, in both cases, peripheral T-cell lymphoma, NOS was characterized by dense proliferation of neoplastic lymphocytes organized in a mantle infiltrated, dissected and/or diffusely replaced in the affected tissues. In the lungs, cell proliferation partially or totally obliterated the alveolar spaces (Fig.5), the bronchiole-alveolar junctions, and the bronchioles, presenting discrete angiocentricity in

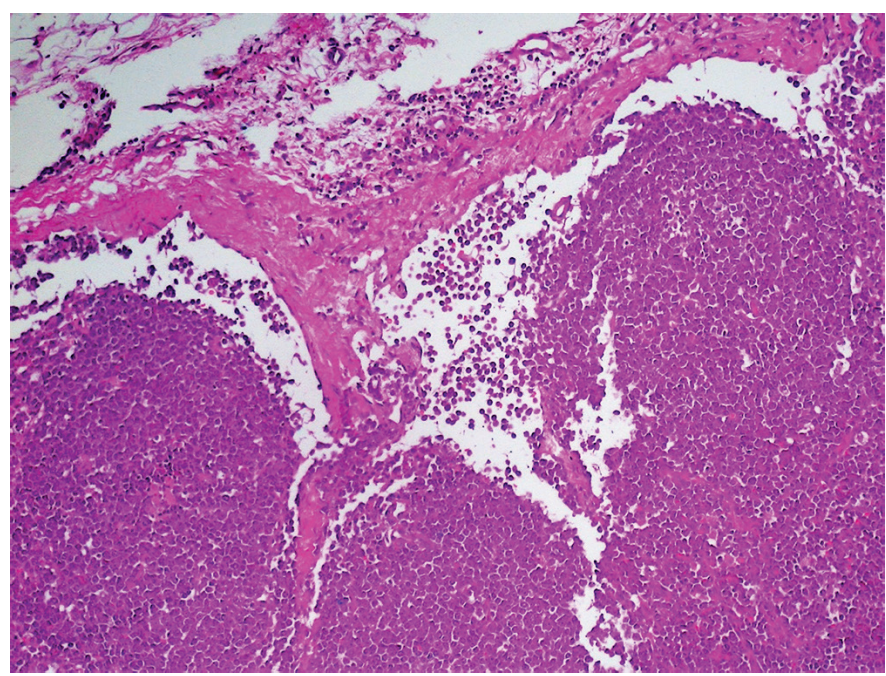

Fig.2. Follicular lymphoma, lymph node, dog. Parenchyma replaced by large coalescing lymphoid nodules. HE, obj.4x.

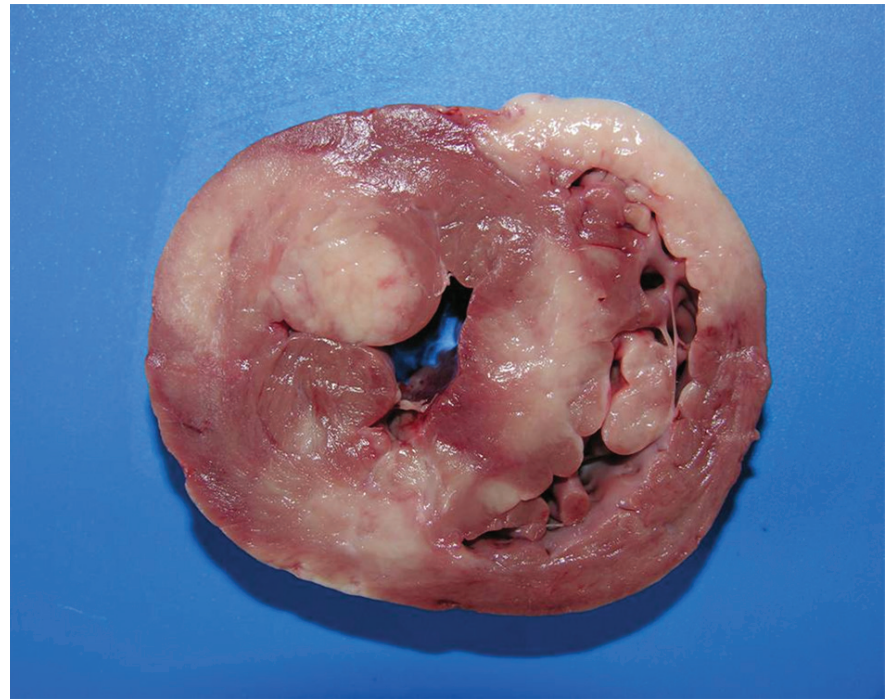

Fig.4. Peripheral T-cell lymphoma, NOS, heart (ventricular cut surface), dog. Yellowish white tissue replaces much of the myocardium in both ventricles and ventricular septum. 
this case. In the heart, cells containing nuclei in the form of a homogeneous, condensed, hyperchromatic mass (apoptosis) next to cardiac fibers (Fig.6), sometimes fragmented, markedly eosinophilic, and surrounded by macrophages containing cell debris (necrosis) were observed in large quantities. The neoplastic lymphocytes presented intermediate volume and were composed of a small amount of homogeneous and eosinophilic cytoplasm. The nuclei were predominantly round, formed by loosely arranged chromatin, containing multiple basophilic, inconspicuous nucleoli (2-4) mostly located peripherally. Moderate nuclear pleomorphism and several mitosis figures, including some atypical, were observed. Both cases showed intense T lymphocyte (anti-CD3) immunostaining and absence of B lymphocyte immunostaining (anti-CD79).

\section{Angiocentric lymphoma}

Of all the dogs diagnosed with lymphoma (n=100), two $(2 / 100)$ were classified as having angiocentric lymphoma. In one of

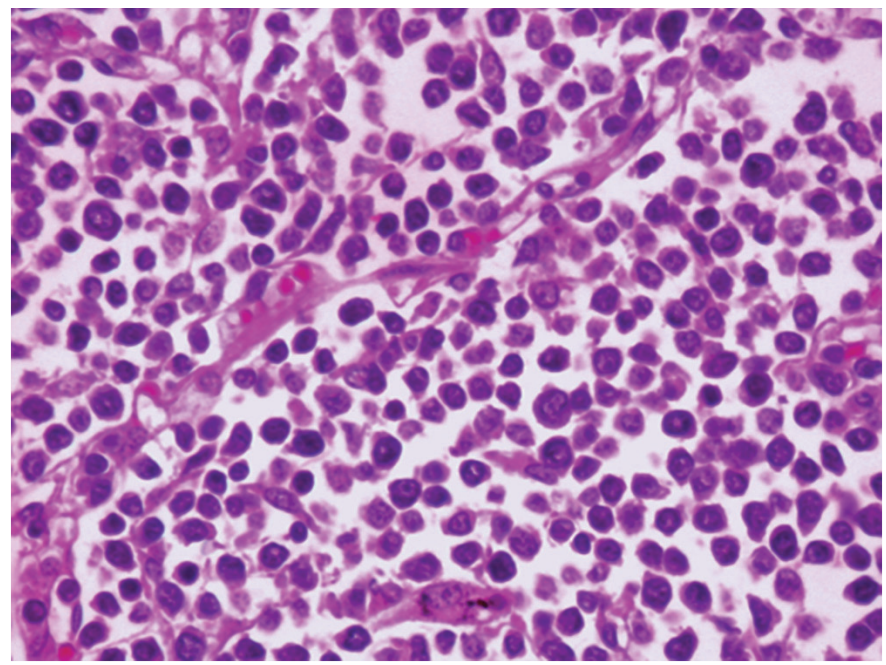

Fig.5. Peripheral T-cell lymphoma, NOS, lung, dog. Alveolar spaces completely obliterated by a mixed population of intermediate volume lymphocytes. HE, obj.20x.

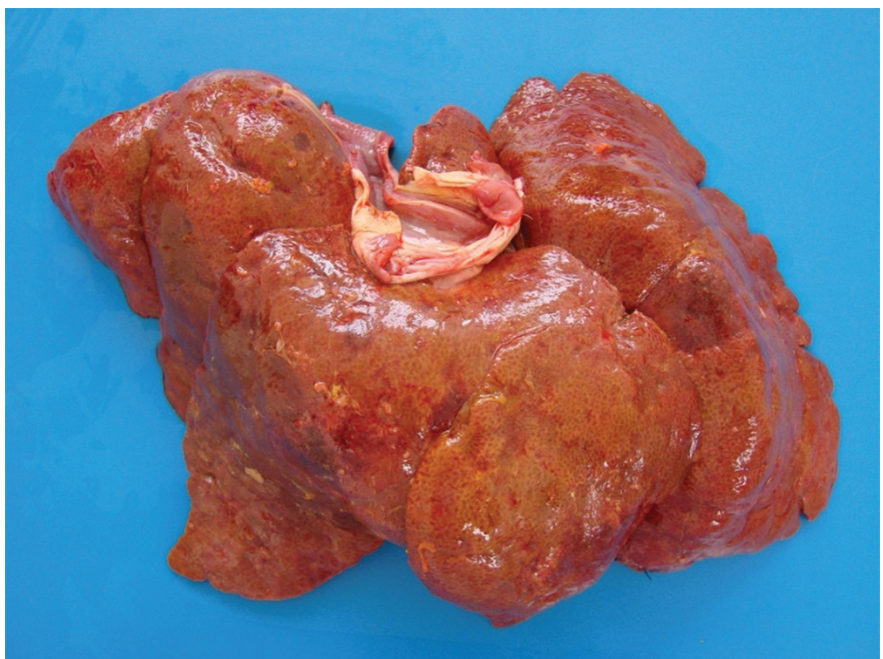

Fig.7. Angiocentric lymphoma, liver, dog. Markedly irregular natural surface, accentuated lobular pattern, areas of parenchymal collapse, and deposition of fibrin films. these cases, the affected organs included the liver, spleen, and submandibular, precapular, axillary, inguinal, mesenteric and popliteal lymph nodes (generalized lymphadenopathy). Macroscopically, the liver was diffuse and markedly enlarged (diffuse hepatomegaly), with rounded lobe borders, and protruding beyond the costal arch. The natural surface was filled with numerous yellowish dots. The organs was firm at cut, with red cut surface containing multifocal yellow dots. The spleen was also diffuse and markedly enlarged (diffuse splenomegaly), and soft to the touch and cut. The cutting surface was homogeneously red. All lymph nodes were diffuse and markedly enlarged in volume (generalized lymphadenomegaly), slightly red, succulent, shiny, and soft. When cut, it was equally soft, with damp cut surface, red and filled with white dots, and with loss of corticomedullar delimitation. In the other case, macroscopically, the liver was the only organ affected, but histologically the bone marrow was also affected. At necropsy, the liver was diffuse and markedly enlarged (diffuse hepatomegaly), brownish, with

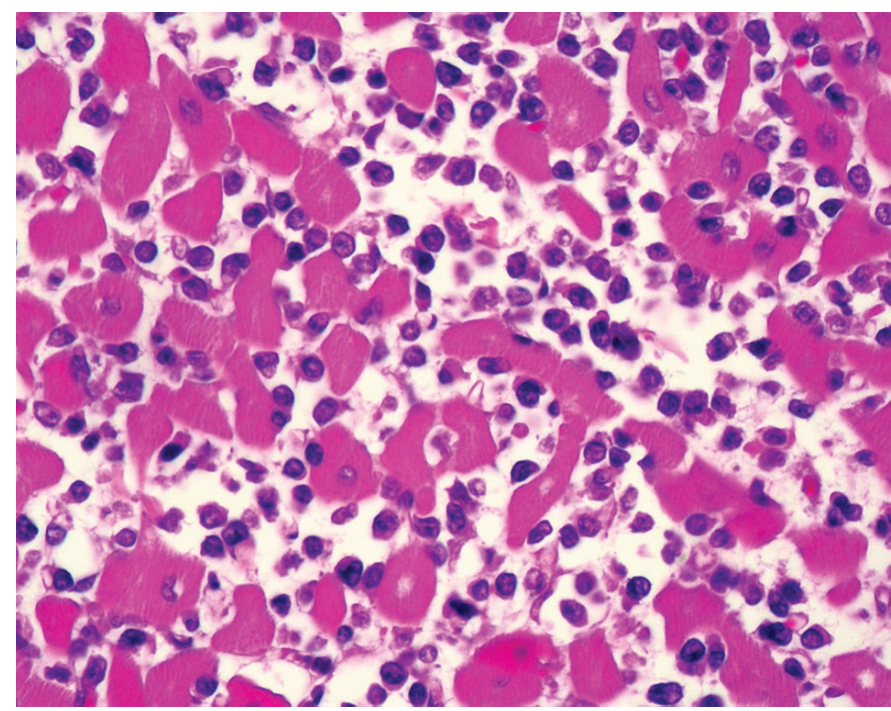

Fig.6. Peripheral T-cell lymphoma, NOS, heart, dog. Marked lymphocyte infiltrate that dissects the cardiomyocytes HE, obj.20x.

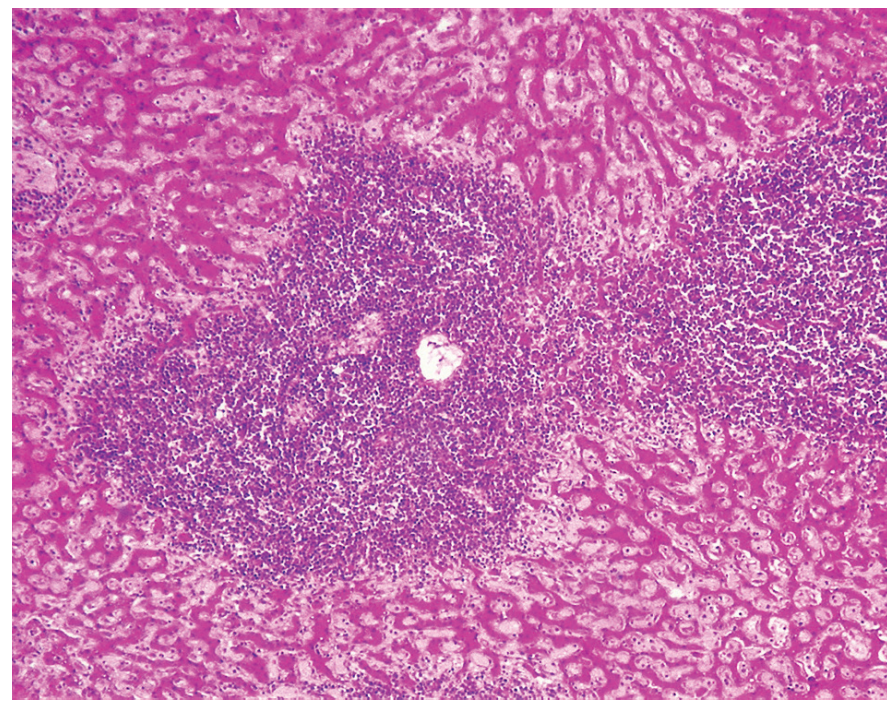

Fig.8. Angiocentric lymphoma, liver, dog. Perivascular lymphoid proliferation that completely destroys the portal area. HE, obj.4x. 
lobe edges, and intensely irregular natural surface, including marked evidence of the lobular pattern (Fig.7), observed on both the natural and cut surfaces. Multifocal dark red areas were observed in some lobes (areas of necrosis) (Fig.7). A moderate amount of filamentous material in the form of a friable yellow film was adhered to the diaphragmatic surface (fibrin) (Fig.7). Areas of parenchymal collapse could be noticed randomly in all lobes. (Fig.7).

Histologically, in both cases, there was dense proliferation of neoplastic lymphocytes forming large cell clusters, predominantly around vessels (angiocentric pattern), causing luminal compression, but with absence or minimal invasion of the vascular wall. In the liver, these cells mainly surrounded the portal spaces, thoroughly dissected, and replaced the connective tissue between the structures (Fig.8). Sometimes neoplastic cells extended from a portal space to the center of the lobe, surrounding the centrilobular vein. In the subcapsular region, along its entire length, clustered neoplastic cells were also observed, forming a cell band. Occasionally, hepatic lobes were observed as areas composed of a grossly flocculent and markedly eosinophilic material near cellular debris (areas of necrosis). In the spleen and lymph nodes, the angiocentric pattern was maintained; however, due to marked cell proliferation, much of the parenchyma had been replaced. Additionally, in the lymph nodes, the subcapsular and peritrabecular sinuses were entirely obliterated by the neoplastic cells. In the bone marrow, capillaries surrounded by cell clusters were more easily identified when they were interspersed with areas of necrosis (Fig.9). The neoplastic lymphocytes had intermediate volumes and a moderate amount of homogeneous and eosinophilic cytoplasm. They contained round or oval, rarely reniform nuclei, located in the central region of the cell, and consisting of loose chromatin. Within these nuclei, single or multiple nucleoli were observed, mostly small, eosinophilic, and variably evident. Such cells were positive for the T lymphocyte marker (anti-CD3) and negative for the B lymphocyte marker (anti-CD79).

\section{Intravascular large T-cell lymphoma}

In this study, diagnosis of intravascular large T-cell lymphoma was observed in two cases (2/100). Of these, one showed exclusive renal involvement and the other presented hepatic nodal (periportal lymph nodes) and cutaneous (scrotum skin) involvement. At necropsy, in the first case, when opening the abdominal cavity, the kidneys protruded from the other organs because they were diffuse and markedly enlarged (diffuse nephromegaly); they were homogeneously yellow and firm to the touch. When cut, they were equally firm, with yellow surface and marked corticomedullary dissociation in which the medulla was approximately five times thicker than the cortex.

In the other case, macroscopically, the liver was diffuse and markedly enlarged (diffuse hepatomegaly), which was evidenced by displacement in its anatomical position in the abdominal cavity, projecting beyond the costal arch by rounding the edges of the hepatic lobes and imprinting the ribs on the diaphragmatic surface. On the natural surface, it was discreetly mottled in white and reddish black (Fig.10), smooth, and soft. The cutting surface was homogeneously red. The periportal lymph nodes were also enlarged (lymphadenomegaly), red, shiny, succulent and soft to the touch. When cut, they were soft, with moist, friable, homogeneously red cut surface, not allowing corticomedullar delimitation. The scrotum was markedly enlarged and a significant amount of a faintly reddish liquid was discharged at cut (hemorrhagic edema - hydrocele).

In both cases, histopathology showed dense round cell proliferation that partially obliterated the lumen of small or medium-sized vessels, but spared the hepatic and renal parenchyma. In the kidneys, proliferation of neoplastic lymphocytes in the lumen of interstitial vessels, exclusively from the medullary region, caused vascular distension and, consequently, collapsed by compression of most of the renal tubules, with only a few collections of collapsed tubules remaining as a reference for organ identification. In the lymph nodes, these cells also obliterated the subcapsular and peritrabecular sinuses. However, there was loss of corticomedullar delimitation macroscopically, but this delimitation was preserved histologically. The neoplastic cells were round, presented distinct cell boundaries and a moderate amount of homogeneous and eosinophilic cytoplasm. The nuclei were round, oval or cleaved, centrally located, and consisting of loosely arranged chromatin. The nucleoli were predominantly single, large, eosinophilic, and conspicuous. Only anisocytosis and anisokaryosis were observed. In the liver, nodal/cutaneous pleomorphism and atypia were accented, and many cells presented beveled, horseshoe shape, or multilobulated nuclei (Fig.11). Multinucleated cells were frequent. At IHC, neoplastic lymphocytes were markedly positive for the T lymphocyte marker (anti-CD3) and negative for the B lymphocyte marker (anti-CD79).

\section{Lymphomatoid granulomatosis}

Lymphomatoid granulomatosis corresponded to two $(2 \%)$ of the 100 cases of canine lymphoma in this study. In necropsied dogs, the lungs, lymph nodes, spleen and liver were jointly affected. The lungs did not collapse upon opening of the thoracic cavity. They were heavy, moist, shiny, pink or reddish black (Fig.12), and soft to the touch. When cut, they were soft, and a small amount of faintly reddish fluid was discharged next to the foam (hemorrhagic edema). The cut surface was homogeneously pink or red. Regarding the lymph nodes affected, they were variably submandibular, retropharyngeal, prescapular, axillary, inguinal, mesenteric and popliteal (generalized lymphadenopathy). All lymph nodes were diffuse and markedly enlarged, red or yellowish white, succulent, shiny, and soft. At cut, they were equally soft, moist, with a homogeneously yellow or reddish black surface, not allowing corticomedullar delimitation. In both cases, the spleen was diffuse and markedly enlarged (diffuse splenomegaly), occupying almost the entire central portion of the abdominal cavity. It was soft at cut, homogeneously red and opaque, with protrusion of the parenchyma over the capsule. The liver was also diffuse, markedly enlarged (diffuse hepatomegaly) and firm, protruding beyond the costal arch. Both the natural and cut surfaces were homogeneously brownish. In one of the two cases (1\%), two other anatomical sites were involved, including the tonsils and esophagus. The tonsils were diffuse and markedly enlarged (diffuse tonsillomegaly), yellowish white, moist and shiny, with loss of pleated conformation, partially obstructing the pharynx. In the esophagus, there were some whitish hemispherical 
nodules, $0.3 \mathrm{~cm}$ in diameter, distributed multifocally through the esophageal mucosa, mainly at the level of the thoracic esophagus. At cut, such nodules were homogeneously white.

In the lungs of both cases (2/100), microscopically, there was dense proliferation of round cells arranged on the periphery of vessels (angiocentric pattern) (Fig.13) and bronchioles (peribronchiolar pattern), but also free, to a lesser extent, within the alveolar spaces, bronchi, and bronchioles. These proliferated cells characterized a mixed population consisting of small mature lymphocytes (scarce cytoplasm with round nuclei formed by dense chromatin), intermediate-sized neoplastic lymphocytes, and histiocytes or macrophages containing a brownish, granular pigment (hemosiderin). Cells with two or more nuclei (binucleated or multinucleated, respectively) were occasionally observed. The neoplastic lymphocytes had scarce, homogeneous, and eosinophilic cytoplasm. Round or oval nuclei formed by loose

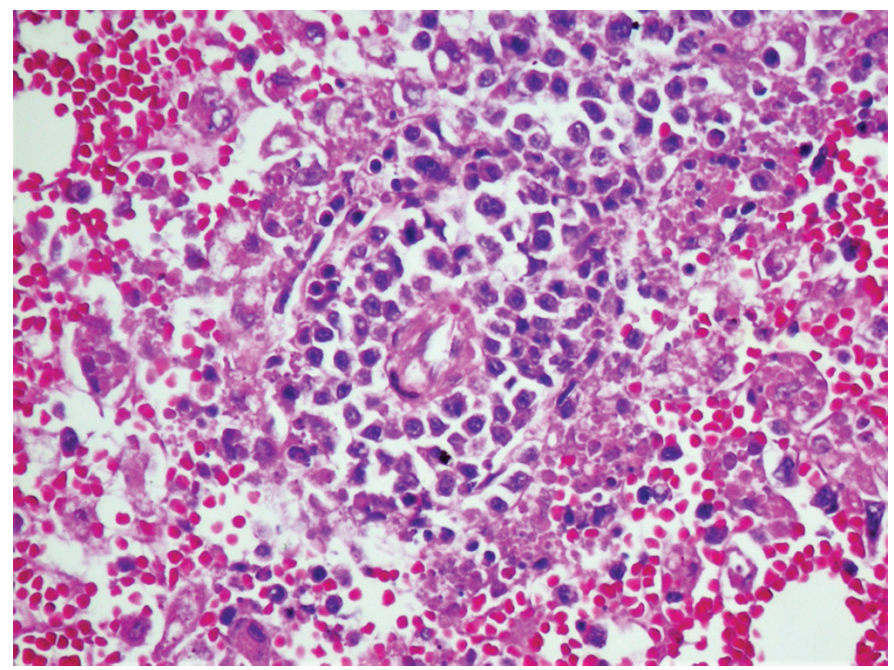

Fig.9. Angiocentric lymphoma, bone marrow, dog. Proliferation of neoplastic lymphocytes forming a cluster around an arterial capillary. There is extensive necrosis and bleeding around these areas. Note the accumulation of macrophages filled with tingible bodies HE, obj.20x.

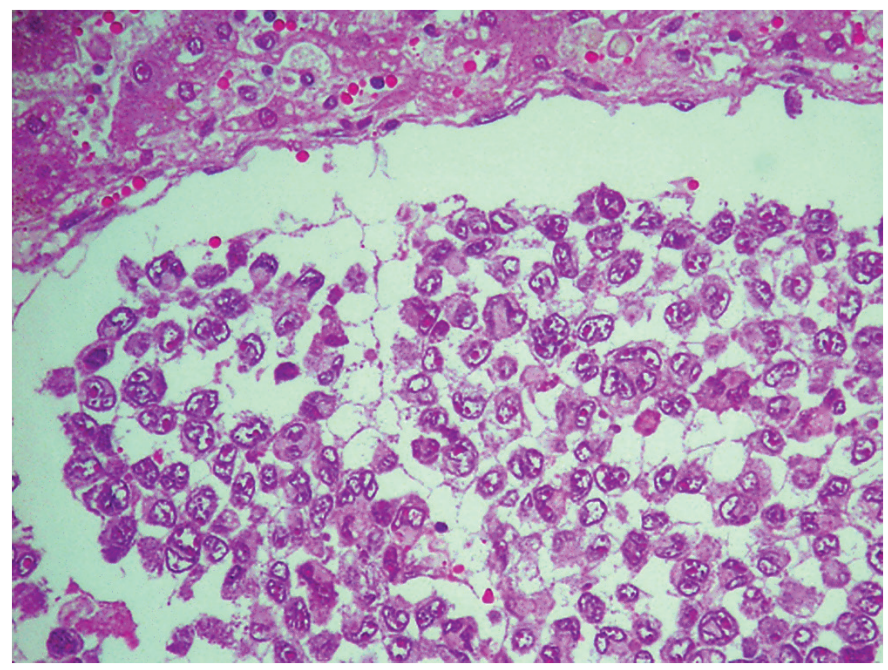

Fig.11. Intravascular large T-cell lymphoma, liver, dog. Intraluminal proliferation of markedly anaplastic neoplastic lymphocytes. HE, obj.20x. chromatin were centrally located. Single, small, basophilic, and variably evident nucleoli were observed. In some places, proliferated cells invaded the vessel wall (angioinvasive pattern) causing it to condense into a homogeneous and markedly eosinophilic material, characterizing fibrinoid necrosis. In both cases, the other affected organs were infiltrated by the same cell population observed in the lungs; however, in the lymph nodes, tonsils, spleen and esophagus, the cells proliferated intensely, coalesced, and replaced the parenchyma, giving the impression of proliferation in a mantle. Differently from the liver, where the angiocentric pattern was maintained, leading to multifocal nodules, especially in the portal spaces. At IHC, neoplastic lymphocytes were markedly positive for the B lymphocyte marker (anti-CD79) and negative for the T lymphocyte marker (anti-CD3). Small mature lymphocytes were immunostained for T lymphocytes (anti-CD3) but not for B lymphocytes (anti-CD79).

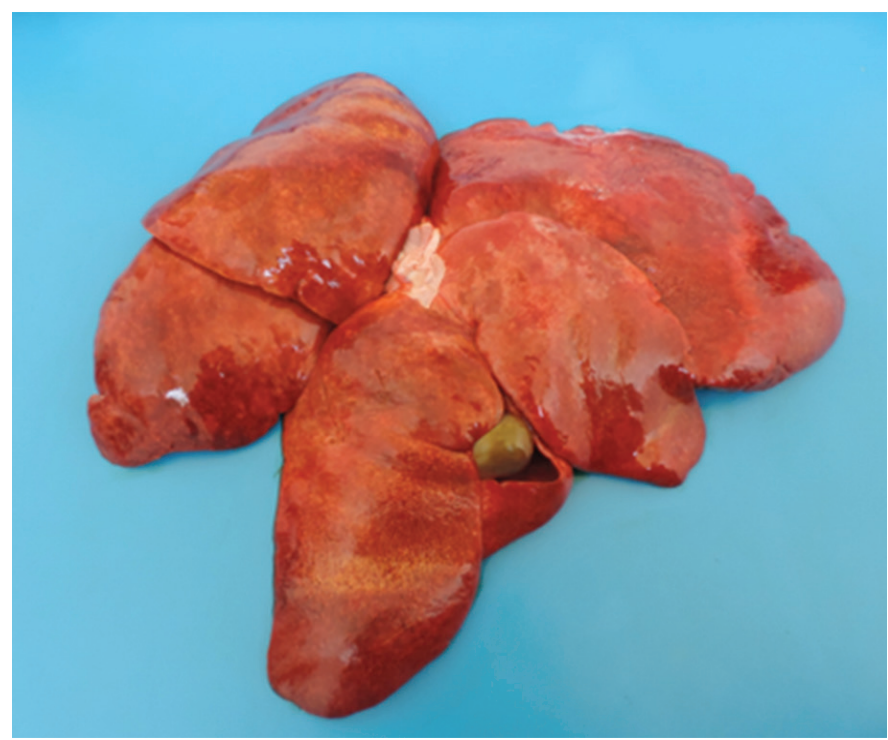

Fig.10. Intravascular large T-cell lymphoma, liver, dog. Hepatomegaly with discoloration and mottle. Note the multiple areas of costal impression.

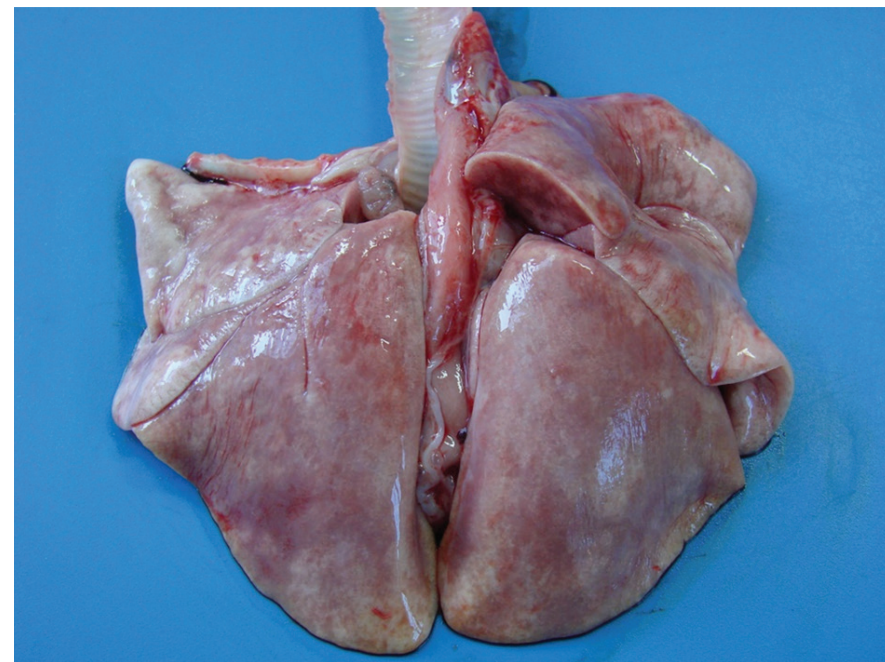

Fig.12. Lymphomatoid granulomatosis, lung, dog. Lack of collapse ("armed lungs") and intense grayness give the organ a hepatized appearance. 


\section{Anaplastic large-cell lymphoma}

Of all dogs with lymphoma $(n=100)$, only one $(1 / 100)$ was diagnosed with anaplastic large-cell lymphoma. In this case, the liver, skin and left axillary lymph node were affected concurrently. At necropsy, distributed multifocally on the natural surface of all hepatic lobes, some non-elevated parenchymal annular areas, whitish and shiny, ranging from 0.3 to $3 \mathrm{~cm}$ in diameter (Fig.14) were observed. They were soft to the touch and cut and presented homogeneously white cutting surface. In the skin of the ventral abdominal region, to the left of the median plane and craniolateral to the prepuce opening, there was an irregular mass measuring $6 \times 4 \times 2.5 \mathrm{~cm}$. In the skin of the right inguinal region, a similar mass measuring $5 \times 2 \times$ $1.5 \mathrm{~cm}$ was observed. Both masses were soft to the touch and cut and presented homogeneously white cutting surface. The left axillary lymph node was diffuse and markedly enlarged, succulent shiny, and soft. At cut, it was equally soft with multilobulated surface, white with yellowish multifocal areas (areas of necrosis) and red dots (hemorrhage), not allowing corticomedullar delimitation.

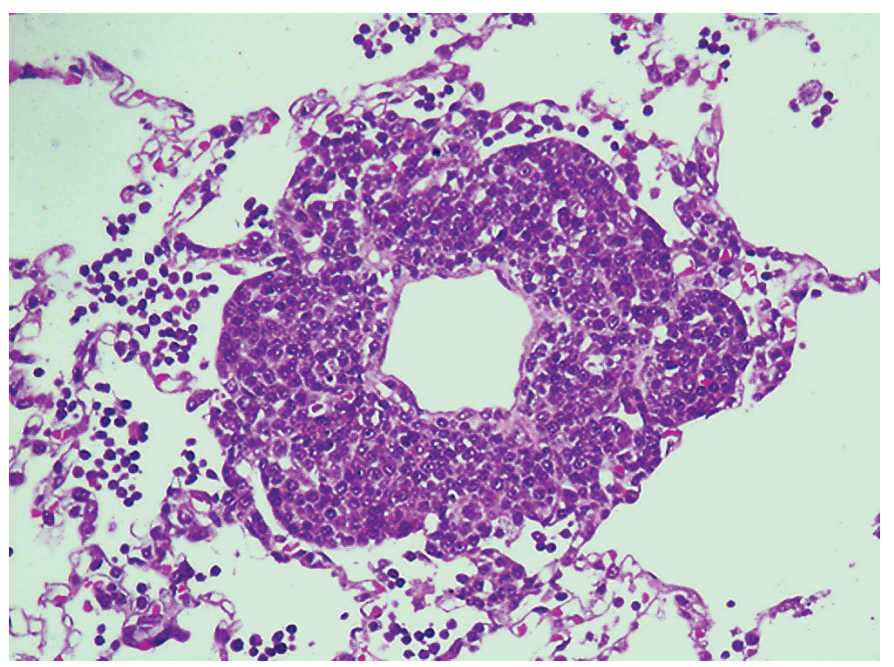

Fig.13. Lymphomatoid granulomatosis, lung, dog. Perivascular lymphoid infiltrate (angiocentric pattern). HE, obj.10x.

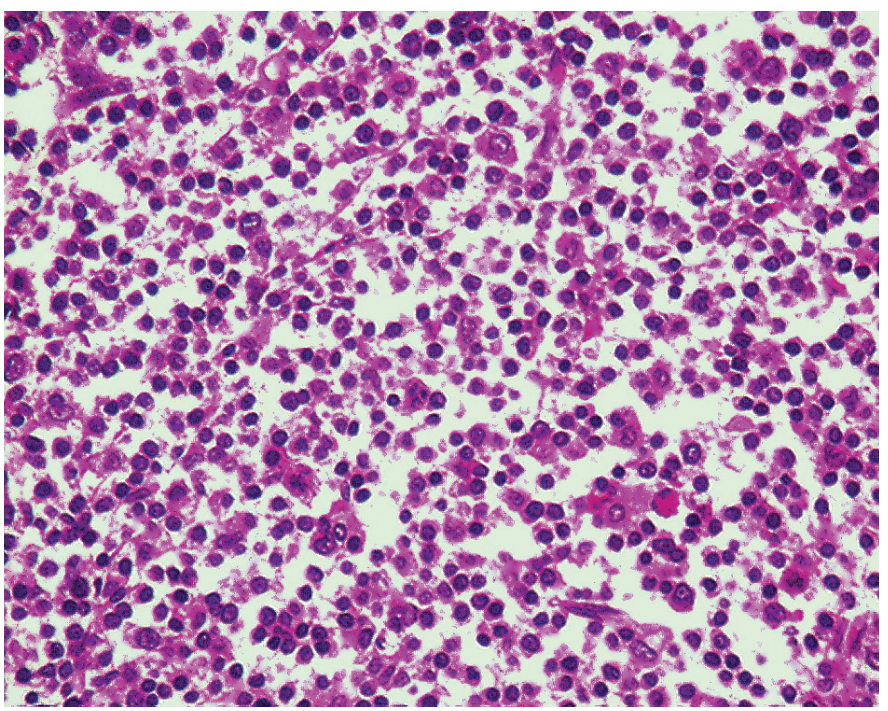

Fig.15. Anaplastic large cell lymphoma, liver, dog. Intensely condensed nucleus lymphocytes ("fried egg" cells"). HE, obj.20x.
The whitish areas observed on the natural surface of the liver, the cutaneous masses, and the left axillary lymph node showed dense proliferation of mantle-organized neoplastic lymphocytes histologically. In the liver, these lymphocytes formed nodules delineated by hepatocytes. In the skin, they replaced much of the superficial and deep dermis, including the cutaneous appendages, but sparing the epidermis. In the lymph node, they obliterated the subcapsular and peritrabecular sinuses, completely replacing the parenchyma, causing "nodal effacement. Neoplastic lymphocytes characterized the small cell variant, represented predominantly by small neoplastic lymphocytes called "fried egg" cells" (Fig.15). Such lymphocytes were composed of scarce, homogeneous and eosinophilic cytoplasm. They had centrally located round nuclei formed by loose chromatin with multiple, small, basophilic and inconspicuous nucleoli. Interspersed with these small neoplastic lymphocytes, but more intensely surrounding vessels, there were large lymphocytes with horseshoe-shaped or reniform eccentric nuclei, sometimes giving the cell an embryo appearance ("hallmark cells") (Fig.16). These cells were

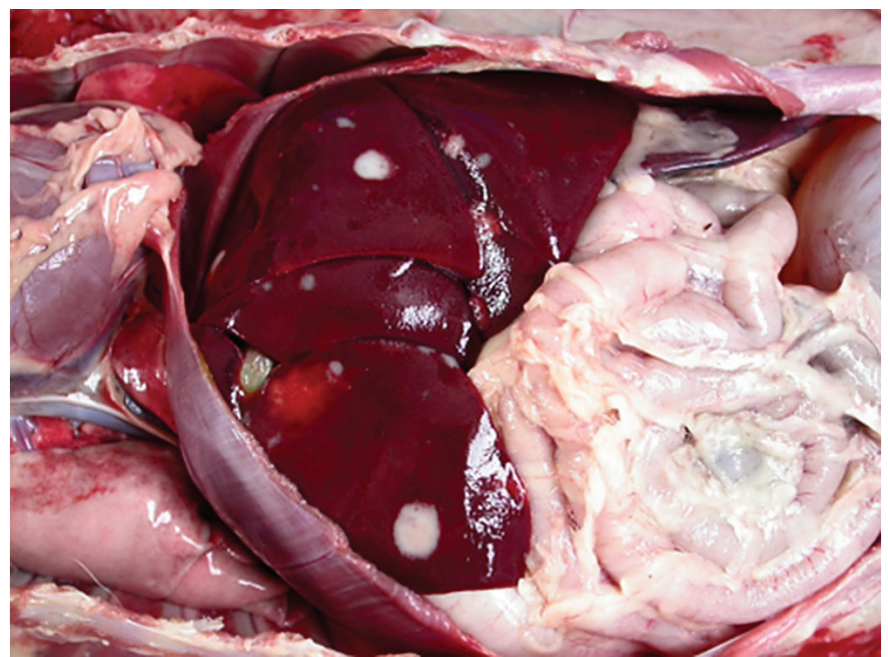

Fig.14. Anaplastic large cell lymphoma, liver, dog. White and nonelevated patches randomly distributed throughout the parenchyma.

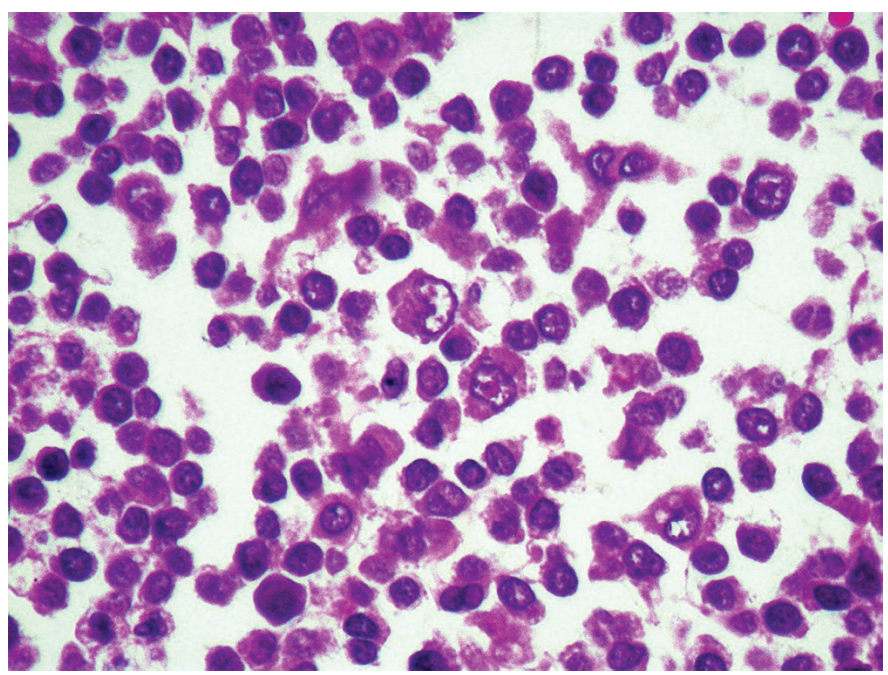

Fig.16. Anaplastic large cell lymphoma, liver, dog. Note a "hallmark cell" in the center of the field amidst variably anaplastic lymphocytes. HE, obj.40x. 
characterized by abundant, homogeneous and eosinophilic cytoplasm, containing nuclei, consisting of loose chromatin. The nucleoli were multiple, medium-sized, basophilic, and more easily observed compared with those seen in small neoplastic lymphocytes. Cells whose horseshoe-shaped nuclei had joined at the ends, presenting the appearance of a donut ("donut cells"), were occasionally visualized. Some large neoplastic cells were binucleated, whereas others were multilobulated or even multinucleated. In some binucleated cells, the nuclei were identical and closely related, arranged as a "mirror image," and large conspicuous nucleoli of "owl-eye shape," much like the Reed-Sternberg cells, were observed. Depending on the cut incidence, some of these hallmark cells showed irregular and eosinophilic intranuclear structures, characterizing false inclusions (pseudoinclusions). Cells whose nuclei were moved to the periphery due to the presence of a large cytoplasmic vacuoles ("signet ring cells") were also randomly observed. At IHC, neoplastic lymphocytes were immunostained for T lymphocytes (anti-CD3) but not for B lymphocytes (anti-CD79).

\section{Hepatosplenic T-cell lymphoma}

Hepatosplenic T-cell lymphoma corresponded to only one case $(1 / 100)$ in this study. In this case, the ocular, oral and genital mucosae, as well as the skin and subcutaneous tissue, were markedly yellow (jaundice) and, in addition to concomitant involvement of the spleen and liver, there was involvement of duodenal and pancreatic lymph nodes (deep localized lymphadenopathy). (Fig.17). Macroscopically, the spleen was diffuse and markedly enlarged (diffuse splenomegaly), occupying much of the abdominal cavity. Multifocal distribution over the diaphragmatic surface was observed in several variable and blackened parenchyma areas (areas of necrosis) (Fig.17). At cut, the spleen was soft with homogeneously red surface, including those blackened areas. The liver was also diffuse and markedly enlarged (diffuse hepatomegaly) with the edges of the lobes markedly bulging, presenting brownish and intensely irregular natural surface (Fig.17). At cut, it was soft with an equally brownish surface. The lymph nodes (duodenal and pancreatic) were diffuse and markedly enlarged (lymphadenomegaly), reddish, showing some elevated blackish parenchyma areas (hemorrhage), succulent, shiny (Fig.17), and soft to the touch and cut. On the cutting surface, they were equally succulent and bright, mottled in white and red, not allowing corticomedullar delimitation.

At histopathology, both organs showed dense proliferation of neoplastic lymphocytes that diffusely infiltrated the parenchyma. In the spleen, the sinusoids and splenic cords (red pulp), as well as the lymphoid nodules, the periarteriolar lymphoid sheaths (white pulp) and the capillary macrophage sheaths were completely replaced by a mantle of neoplastic cells. Multifocal or coalescing areas composed of a grossly floccular and eosinophilic material along with cellular debris and erythrocytes (necrosis areas) were randomly observed. In the liver, the sinusoids were diffusely distended by a large number of neoplastic lymphocytes, forming large areas composed exclusively of neoplastic cells in several places (Fig.18). A large number of these cells also surrounded the portal spaces and dissected the connective tissue between their structures (Fig.18). The nodal parenchyma was diffusely replaced by neoplastic proliferation, similar to what was observed in the spleen, characterizing "nodal effacement. Microscopic evaluation of the bone marrow and lungs revealed the presence of neoplastic cells in both organs. In the bone marrow, a small population of neoplastic lymphocytes was observed interspersed with the normal hematopoietic population. In the lungs, a moderate number of these cells were observed inside the alveolar septal capillaries, suggesting occurrence of leukemization of lymphoma. The population of neoplastic lymphocytes was classically monomorphic, composed of lymphocytes of intermediate volume, with scarce, homogeneous and eosinophilic cytoplasm. The nuclei of these cells were round, centrally located, and composed of dense chromatin. The nucleoli were unique, small, basophilic and inconspicuous. At IHC, such cells were immunostained for T lymphocytes (anti-CD3) but not for B lymphocytes (anti-CD79).

\section{Chronic small B-cell lymphocytic lymphoma, intermediate type}

Chronic small B-cell lymphocytic lymphoma, intermediate type corresponded to one case in this study $(1 / 100)$. At necropsy, the upper and lower eyelids covering the free surface of both eye bulbs were diffusely thickened to the fullest extent, but with greater intensity over the left eye, not allowing their visualization. The posterior (conjunctival) face of the left lower eyelid was exposed due to marked increase in volume. The skin covering the eyelids, especially at the level of the medial angle of the left eye, had hair thinning (hypotrichosis), including the absence of cilia. A moderate amount of mucopurulent discharge partially covered both eyelids and condensed the hairs of the lower left periocular region. Cross sectioning of the skull at the level of the orbits showed that the peri- and intra-orbital adipose body, fasciae and extrinsic muscles of the ocular bulb were diffusely replaced by a homogeneously white tissue, succulent (Fig.19) and soft to the touch, in both eyes. At cut, this tissue was equally soft and presented homogeneously white cut surface (Fig.19). In that same patient, three other sites were affected, including the nasal cavity, tongue and tonsils. Regarding the nasal cavity, cross section of the skull at orbit level showed that the nasal conchae, especially those on the left side of the cavity, were partially replaced by a tissue similar to that observed in the eyelids (Fig.19). As for the tongue, on the dorsal surface, there was a moderate increase in unilateral root volume near the left tonsil and, on the cutting surface, a large amount of the aforementioned tissue largely replaced the lingual musculature.

Microscopically, this white tissue (eyelids, tongue, nasal cavity, and tonsils) was characterized by dense proliferation of neoplastic lymphocytes organized in a mantle that infiltrated and diffusely replaced the affected tissues on both sides. Although macroscopically the ocular architecture was maintained, microscopically, only the sclera and few portions of the choroid coat remained, and the latter presented by some pigmented cells. In the tongue, cell proliferation dissected much of the musculature, but spared the epithelium. In the nasal conchae, the respiratory epithelium was largely replaced, but the bony base of the nasal turbines was maintained. In the tonsils, neoplastic cells formed an extensive mantle that compressed and atrophied but did not invade the lining epithelium. The neoplastic lymphocytes were small and composed of scarce, 
homogeneous and eosinophilic cytoplasm (Fig.20). The nuclei were predominantly round, eccentric, and formed by dense chromatin. Nucleoli were not observed. At IHC, neoplastic lymphocytes were positive for the B lymphocyte marker (antiCD79) and negative for the T lymphocyte marker (anti-CD3).

\section{DISCUSSION}

Most of the scientific literature considers follicular lymphoma in dogs as an uncommon or rare condition, as it accounts for only $6.6(4 / 60)$ to $7.5 \%$ (5/66) of non-Hodgkin's lymphomas in the USA (Valli et al. 2006, Flood-Knapik et al. 2012) and between $0.5(3 / 608)$ and $1.2 \%$ of these diseases in Europe (Arespacochaga et al. 2007, Ponce et al.2010), with a total of only 13 cases described. These data are similar to the prevalence

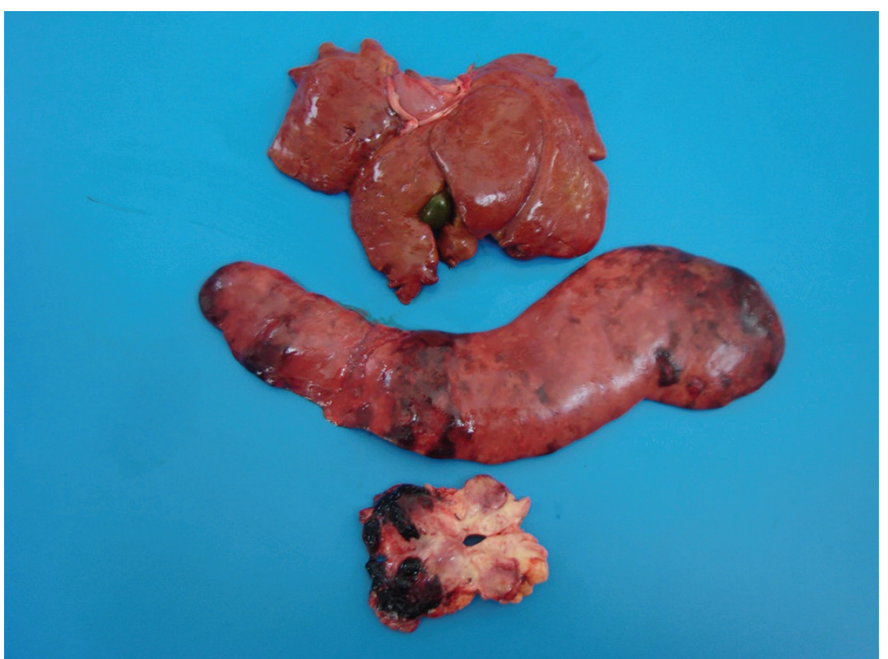

Fig.17. Hepatosplenic T-cell lymphoma, liver, spleen and lymph node, dog. The three affected organs showing diffuse organomegaly Note the areas of hemorrhagic necrosis in the spleen and lymph node.

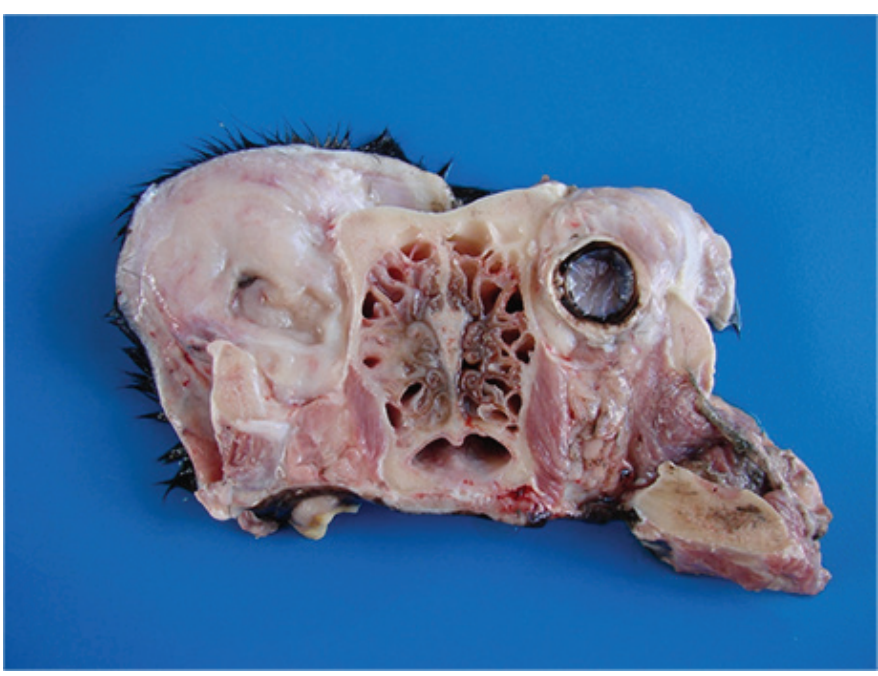

Fig.19. Chronic small B-cell lymphocytic lymphoma, intermediate type, head (cut surface), dog. Whitish mass that replaces intraorbital adipose tissue, fasciae, and extrinsic muscles of the ocular bulb causing bilateral ocular infiltration and compression. Additionally, there is partial replacement of the nasal conchae, especially on the left side of the nasal cavity, by the same tissue seen in the peri-ocular region. found in this study, which corresponded to only $5 \%$ of the lymphoma presentations observed in dogs. Regarding the affected organs, a significant difference was observed between our results and the data published in the literature consulted. According to some authors (Valli etal. 2006, Arespacochaga et al. 2007, Ponce et al. 2010, Flood-Knapik et al. 2012), lymph nodes were the only organs affected in all cases diagnosed as follicular lymphoma, unlike our findings, considering that all cases also presented splenic involvement, observed macroscopically as diffuse splenomegaly, including three different gross presentation patterns. In humans, follicular lymphomas also affect the spleen, bone marrow, Waldeyer's lymphatic ring (formed by the pharyngeal, palatal and lingual tonsils), and peripheral blood, manifesting as lymphocytosis in approximately $10 \%$ of patients (Harris \& Ferry 1992,

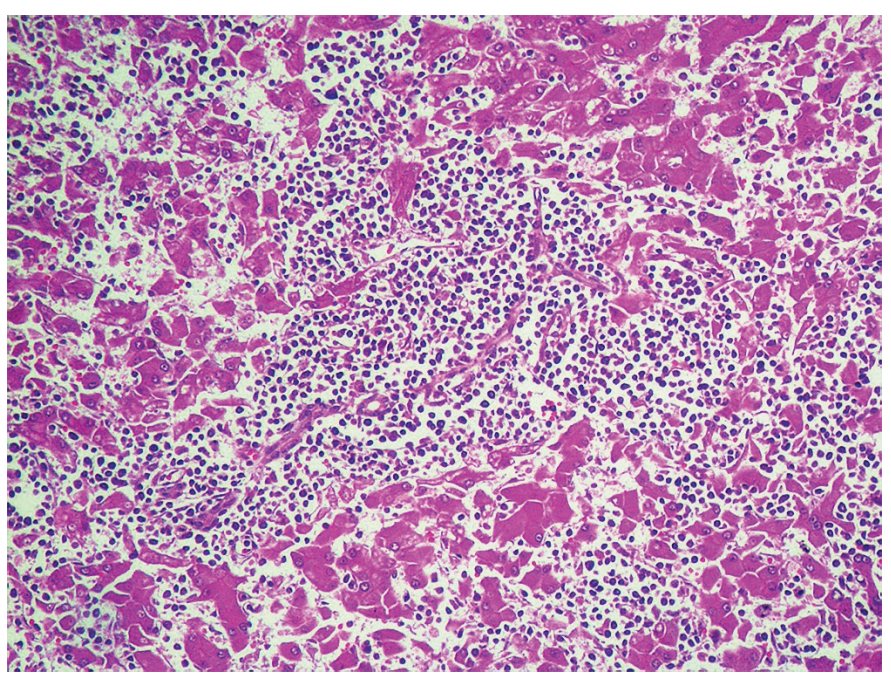

Fig.18. Hepatosplenic T-cell lymphoma, liver, dog. Lymphoid infiltrate that distends the sinusoids, obliterates the portal areas and dissociates the hepatocyte cords. HE, obj.10x.

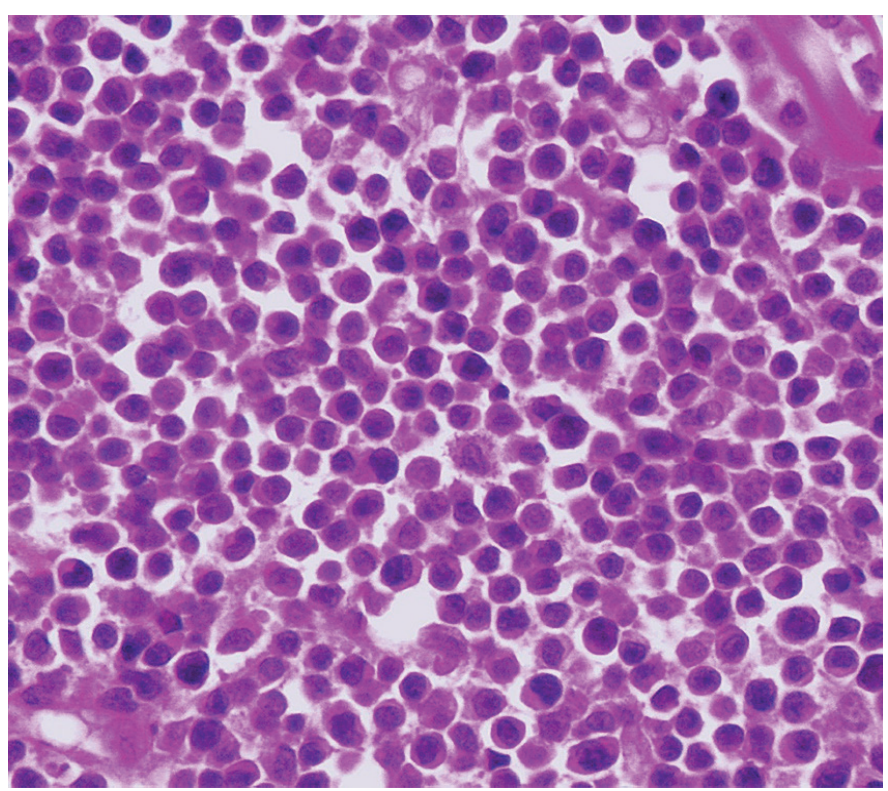

Fig.20. Chronic small B-cell lymphocytic lymphoma, intermediate type, skin (eyelid), dog. Lymphoid proliferation consists of small cells with round and slightly eccentric nuclei formed by aggregate chromatin without nucleoli. HE, obj.40x. 
Harris et al., 2008). Gastrointestinal tract (GIT) and soft tissue involvement may occur as part of a multicenter follicular lymphoma, and other non-hematopoietic organs are rarely primarily affected, including the skin, eyeball attachments, mammary glands and testes (Harris et al 2008). In addition to the evident involvement of the spleen and lymph nodes in follicular lymphoma, the other changes were not observed in the dogs included in this study.

Peripheral T-cell lymphoma, NOS is a group of T-cell lymphomas that have not yet been fully classified and characterized (Valli 2002, 2007, Swerdlow et al. 2017). In human medicine, lymphoma subtypes belonging to this large group have been characterized (according to anatomopathological patterns, biological behavior, and molecular characteristics) reducing the number of lymphomas of this category called nonspecific (Swerdlow et al. 2017); however, this has been slowly performed through immunohistochemical profiles in veterinary medicine, given the limited availability of economic resources for such characterization in animals (Valli 2007). In humans, most patients have a generalized disease characterized by nodal, hepatic, splenic, and cutaneous involvement, but any organ can be affected (Swerdlow et al. 2017). In dogs, involvement is described primarily as cutaneous and/or subcutaneous with or without nodal involvement, with a wide histological variety (Valli 2007, Vezzali et al. 2009). In this study, peripheral T-cell lymphoma, NOS corresponded to only $2 \%$ of the lymphoma presentations diagnosed in dogs in our routine, affecting anatomical sites similar to what is observed in the human literature, but not yet described in the veterinary literature, characterizing a mixed lymphoma (with concomitant involvement of the lungs, stomach, liver, and lymph nodes) and a solitary lymphoma (exclusive cardiac involvement).

The classification of hematopoietic tumors in animals, established by WHO in 2002 and endorsed by the AFIP (Valli 2002), characterizes angiocentric lymphoma as a neoplasm originating from $\mathrm{T}$ lymphocytes, corroborating what was observed using IHC in our two cases. However, only lymphomatoid granulomatosis and lymphomas that develop after skin injections have been established by WHO as angiocentric (Valli 2002). In addition, the most current classifications suggested for hematopoietic tumors in dogs include only lymphomatous granulomatosis as an angiocentric lymphoma (Valli 2007, Valli et al. 2016, 2017), similarly to cases reported in dogs (Berry et al. 1990, Fitzgerald et al. 1991, Shimazaki et al. 2010, Hatoya et al. 2011). Given that the lungs and skin were not affected in either of the two cases of angiocentric lymphoma described here, which would enable the diagnoses of lymphomatoid granulomatosis or post-vaccine lymphoma, respectively, and that the neoplastic lymphocyte population not mixed as classically observed in lymphomatoid granulomatosis, but rather monomorphic, anatomical sites of angiocentric T-cell lymphoma not previously reported in the veterinary literature are described in this study. In humans, nasal extranodal NK/T-cell lymphoma corresponds microscopically (Swerdlow et al. 2017) to the angiocentric lymphoma described in the two cases of this study.

Currently, intravascular lymphoma of dogs is classified as one of the neoplasms originating from mature T cells or NKcells (Valli 2007, Valli et al. 2017), considering the majority of cases already reported in this species (McDonough et al.
2002, Kent et al. 2001, Machado et al. 2011, Ridge \& Swinney 2004), including the cases described herein. In addition to the classification, when cases originating from B cells are occasionally diagnosed, intravascular lymphoma is considered a subtype of diffuse large B-cell lymphoma (Valli et al. 2017). Based on a considerable number of descriptions (Kent et al. 2001, Lane et al. 2012, McDonough et al. 2002, Machado et al. 2011), intravascular lymphoma is, for dogs, a proven condition that presents a high central nervous system (CNS) predilection, affecting it exclusively or concomitantly with several other organs. Nevertheless, in the cases observed in this study, CNS was spared, with concomitant involvement of the liver, periportal lymph nodes, and scrotum in one case, and only of the kidneys in the other.

Lymphomatoid granulomatosis is a mixed lymphoproliferative disorder of primarily neoplastic and non-neoplastic cells, primarily pulmonary, characterized histologically by a pattern of angiocentric and angioinvasive cell proliferation (Berry et al. 1990, Fitzgerald et al. 1991, Park et al. 2007, Song et al. 2015, Swerdlow et al 2017). In both humans and dogs, it is considered a rare presentation of lymphoma, since the lungs do not represent one of the anatomical sites classically affected by this neoplasm (Fry \& McGavin 2012, Fighera \& Graça 2016, Swerdlow et al. 2017, Valli et al. 2017). Corroborating the rarity of its occurrence, lymphomatoid granulomatosis corresponded to $2 \%$ of the lymphoma presentations in dogs in the present study. The macroscopic pattern observed in the lungs and the location of the metastases described herein are similar to what has been reported in the veterinary literature (Berry et al. 1990, Fitzgerald et al. 1991, Park et al. 2007, Hatoya. et al., 2011). However, although lymph nodes, liver, and spleen comprise the major sites of metastasis, any organ or tissue can be affected (Shimazaki et al. 2010, Valli et al. 2017), as it was observed in one case described herein, in which the esophagus and tonsils in addition to the lymph nodes, liver and spleen were sites of metastasis.

In our routine, anaplastic large-cell lymphoma represented only $1 \%$ of diagnosed lymphoma presentations in dogs. This is a rare manifestation of lymphoma, characterized in both humans and dogs by a primarily cutaneous and systemic forms (Valli et al. 2017). In the systemic form, lymph nodes are usually affected concurrently with other sites, including bones, lungs and liver, but skin seems to be the most frequently involved extranodal site (Valli 2007, Swerdlow et al. 2017, Valli et al. 2017). Perhaps the case of anaplastic large-cell lymphoma presented in this study represents the systemic form of this neoplasm, similar to that described in the veterinary and human literature, concomitantly affecting the axillary lymph node, skin and liver; however, based on the findings, it cannot be defined whether the neoplasm could have started on the skin and later involved the axillary lymph node and liver.

Hepatosplenic lymphoma in both humans and dogs is a rare condition characterized by concomitant involvement of the liver and spleen, in the form of diffuse hepatosplenomegaly, and often of the bone marrow, but with no peripheral nodal involvement (superficial lymphadenopathy) (Weidmann 2000, Keller et al. 2012, Swerdlow et al. 2017). In this study, this presentation of lymphoma corresponded to $1 \%$ of the forms diagnosed in dogs in our routine, similar to what is observed in the veterinary literature, which describes only eight cases in dogs (Fry et al. 2003, Cienava et al. 2004, Keller 
et al. 2012). Regarding the affected organs, the case described herein was identical to that observed in the literature, because in seven of the eight reported cases (Cienava et al. 2004, Keller et al. 2012), hepatosplenic lymphoma was invariably characterized by diffuse hepatosplenomegaly with microscopic involvement of the bone marrow and lungs. Based on the human literature (Weidmann 2000, Swerdlow et al. 2017), pulmonary involvement possibly occurred as a result of the advanced stage of the disease and its aggressive behavior. More rarely, jaundice due to diffuse infiltration of the liver by neoplastic lymphocytes and deep localized lymphadenopathy, respectively, has been described in only one case (Keller et al. 2012), corroborating the necropsy findings in our case, in which accentuated jaundice and deep localized lymphadenomegaly of the pancreatic lymph nodes were observed.

Chronic small B-cell lymphocytic lymphoma is one of the five most common types and/or histological subtypes reported in dogs, ranging from 1.8 (Ponce et al. 2010) to $7.8 \%$ (Vezzali et al. 2009) of the cases. However, its so-called an "intermediate type" variant, which is characterized by the presence of lymphocytes with plasmocytic differentiation, is much less common than the classical form (Valli 2002). In our routine, this type of lymphoma, which is considered by many authors, both in humans and dogs, as an indolent form of the disease (Valli 2007, Swerdlow et al. 2017, Valli et al. 2017), accounted for only $1 \%$ of the presentations of lymphoma diagnosed in dogs. Its slowly progressive course is due to a much more cumulative than progressive lymphocyte proliferation, providing longer survival times for patients with this condition (Valli 2002, 2007, Swerdlow et al. 2017, Valli et al. 2017). Usually, the affected sites include the lymph nodes, spleen and liver. Rarely, other sites may be affected, such as the kidneys, adrenals, CNS, eyes, and eye bulb attachments (Valli 2007, Swerdlow et al. 2017, Valli et al. 2017). Given this, the case of chronic small B-cell lymphocytic lymphoma, intermediate type presented in this study represents one of the unusual or rare anatomical sites of this type of lymphoma. In addition, this study presents three other sites not previously described in the veterinary literature as possible sites of this type neoplasm (tonsils, tongue, and nasal cavity [nasal concha]).

\section{CONCLUSIONS}

Although lymphoma is an easily recognized neoplasm among veterinary pathologists, uncommon ( $16 \%$ of the time) non-traditional cases of this important form of cancer can be found. These cases correspond not only to solitary, extranodal and mixed lymphomas, but also to distinct microscopic presentations.

We hope that the results presented here can assist veterinary pathologists with the classification and recognition of cases of "atypical lymphoma" in their anatomopathological routines.

Conflict of interest statement.- The authors declare no conflicts of interest.

\section{REFERENCES}

Arespacochaga A.G., Schwendenwein I. \& Weissenböck H. 2007. Retrospective study of 82 cases of canine lymphoma in Austria based on the Working Formulation and immunophenotyping. J. Comp. Pathol. 136(2/3):186192. <http://dx.doi.org/10.1016/j.jcpa.2007.01.009><PMid:17416237>

Berry C.R., Moore P.F., Thomas W.P., Sisson D. \& Koblik P.D. 1990. Pulmonary lymphomatoid granulomatosis in seven dogs (1976-1987). J. Vet. Intern.
Med. 4(3):157-166. <http://dx.doi.org/10.1111/j.1939-1676.1990. tb00890.x><PMid:2366226>

Cienava E.A., Barnhart K.F., Brown R., Mansell J., Dunstan R. \& Credille K. 2004. Morphologic, immunohistochemical, and molecular characterization of hepatosplenic T-cell lymphoma in a dog. Vet. Clin. Pathol. 33(2):105-110. <http://dx.doi.org/10.1111/j.1939-165x.2004.tb00357.x><PMid:15195270>

Couto C.G. 2010. Linfoma no cão e no gato: oncologia, p.1176-1188. In: Nelson R.W., Couto C.G., Davidson A.P., DiBartola S.P., Hawkins E.C., Lappin M.R., Scott-Moncrieff J.C.R., Taylor S.M., Ware W.A., Watson P.J., Westropp J.L. \& Willard M.D. (Eds), Medicina Interna de Pequenos Animais. 5a ed. Elsevier Ltda, Rio de Janeiro.

Dorn C.R., Taylor D.O. \& Hibbard H.H. 1987. Epizootiologic characteristics of canine and feline leukemia and lymphoma. Am. J. Vet. Res. 28(125):9931001. <PMid:6070962>

Fighera R.A. \& Graça D.L. 2016. Sistema hematopoiético, p.311-405. In: Santos R.L. \& Alessi A.C. (Eds), Patologia Veterinária. $2^{a}$ ed. Roca, São Paulo.

Fighera R.A. 2008. Causas de morte e razões para eutanásia em cães. Doctoral Dissertation, Universidade Federal de Santa Maria, Santa Maria, RS. 172p.

Fighera R.A., Souza T.M. \& Barros C.S.L. 2002. Linfossarcoma em cães. Ciência Rural 32(5):895-899. <http://dx.doi.org/10.1590/S010384782002000500025>

Fitzgerald S.D., Wolf D.C. \& Carlton W.W. 1991. Eight cases of canine lymphomatoid granulomatosis. Vet. Pathol. 28(3):241-245. <http://dx.doi. org/10.1177/030098589102800308> <PMid:1858255>

Flood-Knapik K.E., Durham A.C., Gregor T.P., Sánchez M.D., Durney M.E. \& Sorenmo KU. 2012. Clinical, histopathological and immunohistochemical characterization of canine indolent lymphoma. Vet. Comp. Oncol. 11(4):272-286. <http://dx.doi.org/10.1111/j.1476-5829.2011.00317. $\mathrm{x}><$ PMid:22296667>

Flores M.M. 2016. Aspectos epidemiológicos do câncer em cães da Região Central do RS. 2016. Doctoral Dissertation, Universidade Federal de Santa Maria, Santa Maria, RS. 92p.

Fry M.M. \& McGavin M.D. 2012. System lymphatic, bone marrow, blood cells, and the lymphatic system, p.734-770. In: Zachary J.F. \& Mcgavin M.D. (Eds), Pathologic Basis of Veterinary Disease. 5th ed. Elsevier, St Louis.Fry M.M., Vernau W., Pesavento P.A., Bromel C. \& Moore P.F. 2003. Hepatosplenic lymphoma in a dog. Vet. Pathol. 40(5):556-562. <http:// dx.doi.org/10.1354/vp.40-5-556> <PMid:12949413>

Harris N.L. \& Ferry J.A. 1992. Follicular lymphoma and related disorders (germinal center lymphomas), p.645-674. In: Knowles D.M.(Eds), Neoplastyic Hematopathology. Williams \& Wilkins, Maryland.

Harris N.L., Swerdlow S.H., Jaffe E.S., Ott G., Nathwani B.N., De Jong D., Yoshino T., Spagnolo D., Pileri S.A., Stein H., Thiele J. \& Vardiman J.W. 2008. Follicular lymphoma, p.220-226. In: Swerdlow S.H., Campo E., Harris N.L., Jaffe E.S., Pileri S.A., Stein H., Thiele J. \& Vardiman J.W. (Eds), WHO Classification of Tumours of Haematopoietic and Lymphoid Tissues. 4th ed. International Agency for Research of Cancer (IARC), Lyon.

Hatoya S., Kumagai D., Takeda S., Yamamoto E., Nakanishi M., Kuwamura M., Sugiura K., Sasai H., Yamate J. \& Inaba T. 2011. Successful management with CHOP for pulmonary lymphomatoid granulomatosis in a dog. J. Vet. Med. Sci. 73(4):527-530. <http://dx.doi.org/10.1292/jvms.10-0301> <PMid:21139353>

Helfand S.C. \& Kisseberth W.C. 2010. General features of leukemia and lymphoma, hematologic neoplasia, p.455-466. In: Weiss D.J. \& Wardrop K.J. (Eds), Schalm's Veterinary Hematology. 6th ed. Blackwell Publishing Ltd, Ames.

Keller S.M., Vernau W., Hodges J., Kass P.H., Vilches-Moure J.G., McElliot V. \& Moore P.F. 2012. Hepatosplenic and hepatocytotropic T-cell lymphoma: two distinct types of T-cell lymphoma in dogs. Vet. Pathol. 50(2):281-290. <http://dx.doi.org/10.1177/0300985812451625> <PMid:22711745> 
Kent M., Delahunta A. \& Tidwell A.S. 2001. MR imaging findings in a dog with intravascular lymphoma in the brain. Vet. Radiol. Ultrasound 42(2):504-510.<http://dx.doi.org/10.1111/j.1740-8261.2001.tb00977. $\mathrm{x}><$ PMid:11768516>

Lane L.V., Allison R.W., Rizzi T.R., Stern A.W., Snider T.A., Moore P.F. \& Vernau W. 2012. Canine intravascular lymphoma with overt leukemia. Vet. Clin. Pathol. 41(1):84-91. <http://dx.doi.org/10.1111/j.1939-165X.2011.00399. $\mathrm{x}><$ PMid:22260096>

Machado G.F., Castro M.B., Melo G.D., Ferreira W.L., Aylon E.G. \& Alessi A.C. 2011. Intravascular lymphomatosis in the central nervous system of dogs: immunohistochemical investigation in two cases. Braz. J. Vet. Pathol. 4(1):47-51.

McDonough S.P., Winkle T.J.V., Valentine B.A., Vangessel Y.A. \& Summers B.A. 2002. Clinicopathological and immunophenotypical features of canine intravascular lymphoma (malignant angioendotheliomatosis). J. Comp. Pathol. 126(4):277-288. <http://dx.doi.org/10.1053/jcpa.2002.0553> <PMid:12056776>

Merlo D.F., Rossi L., Pellegrino C., Ceppi M., Cardellino U., Capurro C., Ratto A., Sambucco P.L., Sestito V., Tanara G. \& Bocchini V. 2008. Cancer incidence in pet dogs: findings of the animal tumor registry of Genoa, IT. J. Vet. Med. 22(4):976-984. <http://dx.doi.org/10.1111/j.1939-1676.2008.0133.x> $<$ PMid:18564221>

Park H.M., Hwang D.N., Kang B.T., Jung D.I., Song G.S., Lee S.J., Yhee J.Y., Yu C.H., Doster A.R. \& Sur J.H. 2007. Pulmonary lymphomatoid granulomatosis in a dog: evidence of immunophenotypic diversity and relationship to human pulmonary lymphomatoid granulomatosis and pulmonary Hodgkin's disease. Vet. Pathol. 44(6):921-923. <http://dx.doi.org/10.1354/vp.446-921><PMid:18039906>

Ponce F., Marchal T., Magnol J.P., Turinelli V., Ledieu D., Bonnefont C., Pastor M., Delignette M.L. \& Fournel-Fleury C. 2010. A Morphological study of 608 Cases of canine malignant lymphoma in France with a focus on comparative similarities between canine and human lymphoma morphology. Vet. Pathol. 47(3):414-433. <http://dx.doi.org/10.1177/0300985810363902> <PMid:20472804>

Ridge L. \& Swinney G. 2004. Angiotrophic intravascular lymphosarcoma presenting as bi-cavity effusion in a dog. Austr. Vet. J. 82(10):616-618. <http://dx.doi.org/10.1111/j.1751-0813.2004.tb12604.x><PMid:15887384>

Shimazaki T., Nagata M., Gotokoshino Y., Tsujimoto H. \& Shirota K. 2010. A case of canine lymphomatoid granulomatosis with cutaneous lesions. J. Vet. Med. Sci. 72(8):1067-1069. <http://dx.doi.org/10.1292/jvms.090479><PMid:20234113>

Song J.Y., Pittaluga S., Dunleavy K., Grant N., White T., Jiang L., Davies-Hill T., Raffeld M., Wilson W.H. \& Jaffe E.S. 2015. Lymphomatoid granulomatosis, a single institute experience: pathologic findings and clinical correlations. Am. J. Surg. Pathol. 39(2):141-156. <http://dx.doi.org/10.1097/ PAS.0000000000000328> <PMid:25321327>

Sueiro F.A.R., Alessi A.C. \& Vassalo J. 2004. Canine lymphomas: a morphological and immunohistochemical study of 55 cases, with Observations on p53 Immunoexpression. J. Comp. Pathol. 131(2/3):207-213. <http://dx.doi. org/10.1016/j.jcpa.2004.04.002> <PMid:15276860>

Swerdlow S.H., Campo E., Harris N.L., Jaffe E.S., Pileri S.A., Stein H. Thiele J., Arber D.A., Hasserjian R.P., Le Beau M.M., Orazi A. \& Siebert R. 2017. WHO Classification of Tumours of Haematopoietic and Lymphoid Tissues. 4th ed. International Agency for Research of Cancer (IARC), Lyon.

Vail D.M. 2004. Tumores hematopoiéticos, p.538-555. In: Ettinger S.J. \& Feldman E.C. (Eds), Tratado de Medicina Interna Veterinária. 5th ed. Guanabara Koogan S.A, Rio de Janeiro.

Vail D.M., Pinkerton M.E. \& Young K.M. 2013. Canine lymphoma and lymphoid leukemias: hematopoietic tumors, p.608-638. In: Withrow S.J. \& Vail D.M. (Eds), Withrow \& MacEwen's Small Animal Clinical Oncology. 5th ed. Elsevier, St Louis.

Valli V.E. 2002. Celland NK-cell lymphoid neoplasms, p.39-46. In: Valli V.E., Jacobs R.M., Parodi A.L., Vernau W. \& Moore P.F. (Eds), Histological Classification of Hematopoietic Tumors of Domestic Animals. Vol.2. 2nd ed. Armed Forces Institute of Pathology, Washington.

Valli V.E. 2007. Follicular lymphoma, B-cell neoplasms, p.215-227. In: Valli V.E. (Ed.), Veterinary Comparative Hematopathology. Blackwell Publishing Ltd, Ames.

Valli V.E., Bienzle D., Meuten D.J. \& Linder K.E. 2017. Tumors of the hemolymphatic system, p.203-321. In: Meuten D.J. (Ed.), Tumors in Domestic Animals. 5th ed. John Wiley and Sons Inc, Ames.

Valli V.E., Kiupel M., Bienzle D. \& Wood R.D. 2016. Hematopoietic system, p.102-268. In: Maxie M.G (Ed.), Jubb, Kennedy, and Palmer's Pathology of Domestic Animals. Vol.3. 6th ed. Elsevier, St Louis.Valli V.E., Vernau W., De Lorimier L.P., Graham P.S. \& Moore P.F. 2006. Canine indolent nodular lymphoma. Vet. Pathol. 43(3):241-256. <http://dx.doi.org/10.1354/ vp.43-3-241><PMid:16672571>

Vezzali E., Parodi A.L., Marcato P.S. \& Bettini G. 2009. Histopathologic classification of 171 cases of canine and feline non-Hodgkin lymphoma according to the WHO. Vet. Comp. Oncol. 8(1):38-49. <http://dx.doi. org/10.1111/j.1476-5829.2009.00201.x><PMid:20230580>

Weidmann E. 2000. Hepatosplenic T cell lymphoma: a review on 45 cases since the first report describing the disease as a distinct lymphoma entity in 1990. Leukemia 14(6):991-997. <http://dx.doi.org/10.1038/ sj.leu.2401784> <PMid:10865963> 